\title{
Learning together hand-in-hand: An assessment of students' immersion program in a schools division
}

Sanchez, Richard $₫$

Pampanga High School, Department of Education Schools Division of City of San Fernando, Pampanga, Philippines (chardsanchez23@gmail.com)

Sarmiento, Philip Joseph

Christian Living Education Department, Holy Angel University, Philippines (pjsarmiento@hau.edu.ph)

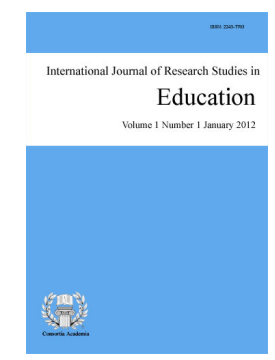

ISSN: $2243-7703$ Online ISSN: 2243-7711

OPEN ACCESS

$\begin{array}{lll}\text { Received: } 8 \text { May } 2020 & \text { Revised: } 13 \text { June } 2020 & \text { Accepted: } 22 \text { June } 2020\end{array}$

Available Online: 26 June $2020 \quad$ DOI: $10.5861 /$ ijrse.2020.5809

\section{Abstract}

This qualitative study is an assessment of the strengths and development needs of a Students' Immersion Program between two schools in a City Schools Division in Pampanga. The study conducted face-to-face interviews with four groups of participants: 24 student-participants who joined the immersion program, 2 parents of the said students, the teachers-in-charge of the program, and the school heads of the partner schools. General findings show that the program failed in so far as increase in academic performance or grades are concerned. Nevertheless, the program is successful in other significant areas like students' attitude towards learning, the improvement of their other development skills, their relationship with other people as students, as a member of the family, and as a member of the community. Since the program is the first initiative in the Division, there were concerns in some of its technical aspects and management. The study finds these concerns as room for improvements that have to be addressed in the implementation of same programs.

Keywords: immersion; partners; strengths; development needs; academic performance 


\section{Learning together hand-in-hand: An assessment of students' immersion program in a schools division}

\section{Introduction}

The issuance of DepEd Order No. 44, s. 2016 (Department of Education, 2016), otherwise known as the Guidelines on the School-to-School Partnerships for Fiscal Year 2016, paved the way for various public schools to strengthen their collaboration with one another through relevant partnerships and agreements for purposes of educational development. In compliance with the said DepEd Order which aims to "strengthen the cooperation, collaboration, and partnership among schools at the local level", the selected leader schools have identified their adopted or partner schools and collaboratively, identified programs that could help the latter reach their full potential and progress.

In a City Schools Division in Pampanga, two schools commenced their School to School Partnership in September 2016. These are School A and the other is School B both located in the same city. As a background, School A has been adjudged as one of the high performing schools in the Division as evidenced by its performance in the National Achievement Test (NAT), in the Performance-Based Bonus (PBB) and other performance indicators and assessments. In fact, it is included in the List of Leader Schools and Allocations found on p. 19 of Annex 1 of DepEd Order No. 44, s. 2016. In the 2014 PBB Performance Category, School A was categorized as Level 7.

Meanwhile, School B has been identified as one of the low performing public schools in the said Division, as far as the above-mentioned indicators are concerned. This fact is even supported by the project ISAP-ISAP (Intensified Student Activities and Programs to Improve School Attendance and Academic Performance) proposed to the Division Office by School B OIC - School Head, last September 9, 2016. Related action research on the same concern, Impact of Center for Students and Co-Curricular Affairs (CSCA) to Address Habitual Absenteeism, was also presented by the same person during the recently concluded Division Research Conference last October 21, 2016.

\subsection{Background of school to school partnership}

Under the School to School Partnership, School A, the high performing school or the leader school, in coordination with School B, the adopted school, identified various programs and/or training that are meant to help the latter improve its performance, both in academics and in governance as well. This School to School Partnership hopes to address the following aspects: (1) Information and Communication Technology Integration, (2) Office Productivity, (3) Critical Thinking and Communication, (4) Access to 21st Century Learning Materials, and (5) Immersion of Students.

Of these five aspects, the Immersion of Students is quite unique in such a way that the targeted beneficiaries or end-users are students; the rest of the programs and/or trainings had School B teachers as end-users. The immersion program aimed to assist the students of School B in their academic life via immersion with the students and in the school of School A for a period of four months. It meant to help them be immersed in a bigger world, to a new culture, a new environment, and a new way of learning. Under the immersion program, twenty-four (24) junior high school (JHS) students of School B were selected to join. This number was comprised of three (3) JHS students per section, coming from the eight (8) sections of the entire JHS department.

The immersion program began in September 2016. This was after the conduct of the orientation to parents/guardians about the program and after securing parental consent from them. From September to December 2016, the selected twenty-four students were supposed to join the respective classes and grade level at 
School A from Monday to Wednesday, and they had to attend to their usual classes at School B from Thursday to Friday. At School A, the School B students still had the same subjects and contents, except that they had different teachers with different teaching approaches and strategies, different classmates with different levels of competence, a different learning environment, among other changes. Doyle (2009) refers to these changes in the immersion program as "temporary homelessness".

After the four-month immersion program, here comes the inquiry on the strengths and development needs of the program that must be addressed. Since immersing or putting the learners to a new learning environment has its own pros and cons, the results of such programs must always be evaluated. Even the processes that such programs have gone through are also factors that must be considered. This is why education administrators and project implementers have to consider various factors in the implementation of such programs. Careful planning, monitoring of the program, evaluation, and other related activities must be in place.

\section{Literature review}

Various studies and academic research have already dealt with the effects and impact of students' immersion to the holistic development of the learners. Although most of these studies dealt with foreign programs such as immersion via travel study program, immersion to different languages, and different communities, their significant contribution to the study on immersion programs and their impact is truly considerable.

Christiano (2014) in his paper entitled The Effects of Multicultural Immersion Programs on Students' Multicultural Competency Development; claimed that although immersion programs do offer a space for growth to the learners, often the programs and their success, or deficiencies, are not properly assessed and measured. This lack of assessment to some immersion programs may result in a certain gap as to the fruitfulness, or lack of the same, of such programs. In the same study, he proposed various ways on how to embrace better practices on immersion programs through the discussion of the multiple facets of multicultural competency development related to travel study programs. He concluded that the increasing importance of immersion programs via travel study programs should commensurate with the demand for proper assessment and evaluations of such programs.

According to Braskamp, Braskamp, and Merill (2009), learners nowadays should not confine themselves to what the four corners of their classroom offer. Rather, they should seek the opportunities that other rooms for improvement and global competence do offer. He proposed that learners have to experience different cultural backgrounds, different perspectives, different customs, and different aspirations. But just like other studies, a caution on the proper implementation of immersion programs was also mentioned and recommended. Furthermore, Ogden (2006) claims that the biggest challenge to educators nowadays is how to engage the learners in "a meaningful intellectual and intercultural experiences". He claimed that more than an increase in academic performance, the more challenging task is how to let the learners go out of their comfort zones and to think globally. More than the numbers, one factor that should be assessed is their reception and attitude towards learning and towards relating themselves to the new environment they currently belong to. This is supported by Steinberg (2002) who claimed that implementers of immersion programs should develop instruments that can actually measure learners' overall growth holistically.

Another author, Greenholtz (2000), reminded academic institutions that learning goals and objectives must not just be confined in the context of the study, but more importantly, they should be geared towards the development of well-rounded human beings. This is why the significance of immersion to another culture or environment must be in place. In addition, Doyle (2009) suggested in his study that the employment of both quantitative and qualitative approaches in the assessment of immersion programs is beneficial since it will truly measure the extent of the holistic intercultural growth of the learners. While, Paus and Robinson (2008), again referring to travel study programs as immersion, note that these programs "provide unique opportunities for students to learn about and appreciate cultures and perspectives different from their own, to confront and explore their own assumptions, to achieve greater proficiency in another language and to grapple with the challenge of 
living in an unfamiliar context". This is supported by Kolb (1984) who claimed that direct exposure to a particular population will greatly benefit people who are undergoing immersion programs.

All of these studies share the common view that the true benefits of any immersion program will only be gauged through proper and appropriate assessment and evaluation. The impact of any immersion program to the learners is indeed a factor that must always be put to a test. Thus, this study was conducted. Through this study, the four-month immersion of School B students to School A was properly assessed and evaluated for purposes of addressing areas for improvements, specifically that the partnership programs are conducted on a regular basis by public schools that qualify for the criteria set forth under the School-to-School Partnerships.

\subsection{Research questions}

This undertaking sought to determine the strengths and development needs of the Students' Immersion Program between the School A and the School B. Specifically, it sought to answer the following questions:

1. What are the strengths of the program in terms of the following aspects?
A. Students' participation in the program;
B. Students' academic performance;
C. Students'skills development
D. Students' attitude towards learning;
E. Students' relationship with other people; and
F. Management of the program.

2. What are the development needs of the program in terms of the aspects mentioned above? What could still be done to further improve the program and its implementation in the following years?

\subsection{Significance of the study}

The results of this study will help implementers continue with the best practices that are already in place. They may also use the same results to improve or modify certain details of the Students' Immersion Program to achieve its goals. Decision making on the part of the government will also be easier because if approved, this undertaking will give the government evidenced-based data as to the success, or deficiencies, of its programs. The said results can be utilized in the proposal of action plans, policy formulation, and development.

Specifically, this study finds its significance in two areas or fields: 1) in the teaching-learning process; and 2) in the school governance as well.

$>\quad$ For the government, it is hoped that this study may help it determine programs or projects that need attention or priority, particularly in terms of funds allocation.

$>\quad$ For the Schools Division, specifically its two involved schools, School A and School B, it is hoped that this undertaking will help them determine research-based strengths of the program that deserve continuity, and the areas that require improvement, modification, or attention.

$>\quad$ For the student-participants in the Immersion program, specifically for those who have successfully finished the program, the study will serve as an opportunity or an instrument that will show what they have gone through in the past four months, the programs' impact in their academic life, in their attitude towards learning, and in other areas of their life that may be directly or indirectly affected by the program. 
For those students who were unable to finish the program, this study will serve as an opportunity for them to scientifically voice out their concerns and reasons for withdrawing in the program.

$>$ For other institutions that plan to conduct the same program, this study may likewise serve as a guide on how they could effectively implement their own programs.

\section{Methodology}

\subsection{Research design}

The study employed a basic qualitative research method. According to Creswell (2007, p. 37), "Qualitative research begins with assumptions, a worldview, the possible use of a theoretical lens and the study of research problems inquiring into the meaning individuals or groups ascribe to a social or human problem". He wrote that this method commences when one places himself into the natural setting of the participants, observing them, and trying to find meaning and value to their inputs. He elaborated that, "To study this problem, qualitative researchers use an emerging qualitative approach to inquiry, the collection of data in a natural setting sensitive to the people and places understudy, and data analysis that is inductive and establishes patterns or themes". Citing Denzin (1978) and Lincoln and Guba (1985), Creswell wrote that in qualitative research, the researchers place themselves into the world, interpreting and giving meaning certain phenomena as people provided to them. Interviews, conversations, and other means of communication may be used by the study to gather pertinent data. When the process culminates, the results are no other than the true voices and opinions of the participants described in scientific means. In the present study, basic qualitative research is the most suitable design as the purpose is to explore the various areas of the immersion program as viewed and told by the individual participants. In using the qualitative method, the study attempted to dig deeper into the program's various areas through in-depth analysis.

\subsection{Respondents and sampling}

There were thirty (30) participants in this study. These include the following: a) the respective school heads of the School A and School B; b) one teacher each from the two schools; c) two parents from School B; and d) twenty-four Junior High School students from School B. The respective school heads of the partner schools were selected based on their participation as initiators and leaders of the students' immersion program. On the other hand, the teacher from each of the two schools was selected because of his/her direct participation or involvement in the said program. The two parents at School B were selected based on their active involvement in the school, specifically in the immersion program. Lastly, the twenty-four JHS students from School B are the ones who had participated either fully or partially in the program.

In general, purposive sampling was employed in selecting the four groups of participants: the school heads, the teachers, the parents, and the students. In this method of selection, the participants are chosen based on their characteristics and the objectives of the study. This method is also known as judgmental, selective, or subjective sampling. In view of the confidentiality clause in research, the identities of the respondents are kept confidential. For the student-participants, the study used the codes S1 to S24, meaning Student Number 1 up to Student Number 24. The parents' codes are P1 and P2.

\subsection{Instruments}

The study used the expert-validated interview guides as the instruments in the data gathering which is a face-to-face interview with the participants. There are four different interview guides for the four groups of participants in the study. This is because varied information is needed from the groups of participants to successfully meet the objectives of the study. This is in addition to the fact that the researcher himself acted as a key instrument in the data collection process. As a key instrument, the researcher tries to respond directly to the 
Sanchez, R., \& Sarmiento, P. J.

necessities and demands of the data gathering, applying flexibility in the process, avoiding prejudices, and adhering to objectivity and fairness.

\subsection{Data collection and ethical considerations}

As for the procedures of the data gathering, it commenced from sending invitation letters and informed consent forms, together with the interview guides, to the invited participants. Parental consent as applicable to the student-participants in the study was also secured. With their acceptance of the invitation, face-to-face interviews were conducted in their respective offices or locations. The research focused on the participants' perspectives, the meanings that they gave, and their subjective views on the matters presented to them. Additionally, since the study involves a program between two schools, permission to conduct the study and use data for purposes of academic research was secured.

\subsection{Data analysis}

Data gathered were analyzed systematically. From the results of the face-to-face interviews with the participants, trends, norms, or themes were explored and identified. Specifically, the study employed coding, categorizing, and thematic analysis in the treatment of the data gathered. The processing of the pertinent data gathered from the interviewed participants consisted of the verbatim transcription of their interviews. Those data coming from the participants who were interviewed in the Filipino language and answered in the same language were translated into the English language immediately after the verbatim transcription. These were then organized based on the requirements of the objectives of the study. These data were subjected to Data Analysis Matrix as used in Creswell and Plano Clark (2007). The said matrix, now modified to fit the cause of this study, consists of the following:

First is the preparation of the data for analysis. This is done through the transcription of the interview data in verbatim. Second is the exploration of the data, done through the coding of the data, and aligning them in accordance with the objectives set in the study. The third is the data analysis proper, done through the classification of the coded data to create syntheses of ideas as required by the study. Fourth is the representation of the data analysis, done by deducing the factors that show the strengths and development needs of the immersion program based on the syntheses of the responses, input, or views of the participants in the study. Finally, the validation of the data was conducted. This was done through the explanation of the conclusions in the study and relating them with the proposed presentation of the program's assessment.

\section{Findings and discussions}

After doing the coding, categorizing, and thematic analysis of the transcribed verbatim face-to-face interviews, the emerging themes were identified. Findings of study are presented in Table 1.

\section{Table 1}

Emerging themes of the study

\begin{tabular}{|c|c|c|}
\hline Research Questions & Overall Theme & Individual Themes \\
\hline $\begin{array}{l}\text { 1. What are the strengths } \\
\text { of the program in terms of } \\
\text { the following aspects? } \\
\text { i. Students' participation in } \\
\text { the program; }\end{array}$ & $\begin{array}{l}\text { The program's success heavily relies on } \\
\text { parameters and factors other than numbers or } \\
\text { the academic performance and class report } \\
\text { cards of the student-participants. } \\
\text { Statistically, if the results of the immersion } \\
\text { program will only be measured through the } \\
\text { resulting academic performance of these } \\
\text { people, the program definitely failed. } \\
\text { Nevertheless, there is still great success and } \\
\text { optimism in the implementation of the } \\
\text { program in so far as other aspects or }\end{array}$ & $\begin{array}{l}\text { It is commendable that at the beginning of the program, } \\
\text { student-participants and their parents have shown support } \\
\text { to it through their participation. }\end{array}$ \\
\hline
\end{tabular}


Learning together hand-in-hand: An assessment of students' immersion program in a schools division

\begin{tabular}{ll}
\hline ii. Students' academic & $\begin{array}{l}\text { developments are concerned. The highly } \\
\text { performance; }\end{array}$ \\
& $\begin{array}{l}\text { developed skills of the students specifically } \\
\text { in critical thinking, their resulting attitude } \\
\text { towards learning, the program's effect on } \\
\text { their relationship with other people, their }\end{array}$ \\
& immersion to a new learning environment, \\
& the insights they gained, all contribute to the \\
iii. Students' skills & success of the program in general. Here \\
development & immersion program went beyond the \\
& numbers and touched the very heart and \\
& awareness of the student-participants on the \\
& value of education and holistic development.
\end{tabular}

iv. Students' attitude

towards learning;

v. Students' relationship

with other people; and

vi. Management of the

program.

\section{What are the}

development needs of the

program in terms of the

aspects mentioned above?

What could still be done to

further improve the

program and its

implementation in the

following years?

i. Students' participation in

the program;

ii. Students' academic

performance;

\section{iii. Students' skills \\ development}

iv. Students' attitude

towards learning;

\begin{tabular}{l}
\hline v. Students' relationship \\
with other people; and \\
\hline vi. Management of the \\
program.
\end{tabular}

v. Students' relationship

vi. Management of the

The study cannot cite 'strengths' in this area because on

the basis of numbers, of academic performance at School

$\mathrm{B}$, the program failed since most of the

student-participants got lower grades compared to their

numbers before they joined in the program.

Certain development skills in some of the

student-participants like their listening skill, reading, writing, drawing, their critical thinking, the data prove that all were highly developed and nurtured in their stay in the immersion program. Aside from these, the School A

ICT integration was also a big factor that enabled some of the School B students in their realization that they can still do many things and the technology is there to equip them with what they need in the 21 st century learning.

The student-participants who actually started and finished the immersion program are optimistic that the program served its true purpose - it made them see the bigger world. The program opened many doors to students. The program allowed the participants to deal with various kinds of people. It opened them to the true value of learning, of education as a whole.

For students who started and finished the program on the agreed period, being friendlier, more sociable, an increased self-esteem, stronger connections with people around them, among other benefits, all of these manifest flying colors for the program.

The partner schools are commended for taking the initiative to conduct the immersion program which was actually the first in their Schools Division.

The program implementers failed to secure the commitment of the students to start the program and finish the same on the supposed duration of time. The program may be improved in the next implementations if the partner schools, together with the support and commitment of both students and their parents, can really device certain mechanisms to ensure the commitment of all parties to start and finish the program on an agreed duration or period. Contract of agreement and other incentives may also be crafted and provided for students who can complete the immersion program.

As mentioned in the Discussion, students' various reasons for not completing the immersion program on the agreed period have to be seriously considered, discussed, and addressed by the partner schools so that commitment to start and finish the program may be ensured in the next implementation of the program.

It would still be better and the program may be improved in the next implementation if the grades of students before and after the implementation of the immersion program are statistically compared. This would just mean that as prerequisite to this comparison, students should be able to start and finish the program on the agreed period of time and that they should be staying in School A everyday and the arrangement or schedule of 3-day-School A and 2-day-School B is replaced. Otherwise, such comparison would be very difficult, if not confusing.

As discussed in the preceding paragraphs, students' skills development, their attitude towards learning and their relationship with other people have actually improved. However, it can be observed that this can only be true for students who actually started and finished the immersion program on the agreed duration or period. This is why as an area for improvement, the study reiterates on students' commitment to the program.

The program may be improved through a better orientation on the purpose or objectives of the program, better communications to parents and a closer monitoring and evaluation of its implementation.

As regards the participation of the students in the immersion program, it is commendable that at the beginning of the program, student-participants and their parents have shown support to it through their 
participation. However, the findings also show that the program implementers failed to secure the commitment of the students to start the program and finish the same on the supposed duration of time. This is alarming because of the fact that just like any program or project, commitment to the same is very important for it to be successful (DeBar et al., 2011).

In the immersion program of the participants, it was found out that such commitment was not present. The partner school failed to devise a mechanism or, maybe, a "win-win solution" on how to assure such commitment to the program and avoid the concern of having some persons to replace the slots previously given to other students. However, this failure cannot be solely blamed to the partner school because of the fact that no matter how it tried to hold the original batch of students who joined the program, it was powerless against the wishes of the parents/guardians in withdrawing the consent they have previously given to the school. Doing otherwise would result in legal battles that no school would want to experience. The program may be improved in the next implementations if the partner schools, together with the support and commitment of both students and their parents, can really device certain mechanisms to ensure the commitment of all parties to start and finish the program on an agreed duration or period. Contract of agreement and other incentives may also be crafted and provided for students who can complete the immersion program.

The data note that from the original 24 student-participants, only 3 were able to finish the program in its duration of 4 months. Most of the student-participants stayed in the program for either 2 months or 3 months only. There are even participants who stayed in the program for only 6 days, 5 days, and 2 days. Overall, there were 3 batches of participants in the immersion program. The first batch was the ones who started the program at the beginning of September 2016. The second batch includes those who participated in the program either in mid-September or October 2016. The last batch of participants was the ones who joined the program only in November 2016. The major reasons given by these people who quit in the program are the following: poor grades, non-submission of projects due to economic constraints, non-recording of their School A quizzes, or performances by their school (School B), lack of lectures, and confusion on some of the lessons. Some minor or unique reasons are difficulty in waking up too early, lack of interest in the program, and other trivial reasons. These reasons for not completing the immersion program on the agreed period have to be seriously considered, discussed, and addressed by the partner schools so that commitment to start and finish the program may be ensured in the next implementation of the program.

On the concern on academic performance, the study cannot cite 'strengths' in this area because on the basis of numbers, of academic performance at School B, the program failed since most of the student-participants got lower grades compared to their numbers before they joined in the program. This is evidenced by their class report cards and the letters received by the school from the parents withdrawing their parental consent for their children to join in the program. Most reasons cited by the parents in the said instruments are poor grades of their children. Although technically, the study believes that such a scenario could not be totally related to the students' immersion program because of the issue of incomplete participation in the program as mentioned in the preceding paragraphs. Were the resulting poor grades totally related to students' immersion program given the fact that the schedule is 3-day and 2-day at the School A and School B, respectively? Was it proper to completely connect the resulting poor academic performance when some students stayed in the program for only a few weeks? The study is convinced that it is not in the affirmative. Nevertheless, it would still be better and the program may be improved in the next implementation if the grades of students before and after the implementation of the immersion program are statistically compared. This would just mean that as a prerequisite to this comparison, students should be able to start and finish the program on the agreed period of time and that they should be staying in School A every day and the arrangement or schedule of 3-day-School A and 2-day-School B is replaced. Otherwise, such a comparison would be very difficult, if not confusing.

Surprisingly, despite all these concerns, the study finds great success in the program in so far as other parameters or aspects are concerned. Certain development skills in some of the student-participants like their listening skill, reading, writing, drawing, their critical thinking, the data prove that all were highly developed and

92 Consortia Academia Publishing (A partner of Network of Professional Researchers and Educators) 
nurtured in their stay in the immersion program. Aside from these, the School A ICT integration was also a big factor that enabled some of the School B students in their realization that they can still do many things and the technology is there to equip them with what they need in the $21^{\text {st }}$-century learning. The integration of ICT materials in the teaching-learning process and the conduciveness of the learning environment at the School A made the student-participants open to various possibilities in education.

Despite the setback in other aspects particularly on the supposed increase in academic performance, the student-participants who actually started and finished the immersion program are optimistic that the program served its true purpose - it made them see the bigger world. The program opened many doors to students. It allowed them to deal with various kinds of people. It opened them to the true value of learning, of education as a whole. From their responses, the study finds new people, born again people who are enlightened with the end goals of education which is to prepare them for their future (Larson \& Miller, 2011). For students who started and finished the program on the agreed period, being friendlier, more sociable, increased self-esteem, stronger connections with people around them, among other benefits, all of these manifest flying colors for the program. Even the parent-participants agree to these positive outcomes in their children. These results come from the way the School A people accommodated School B students. From the point of view of the latter, they like most in the immersion program the School A teachers' and students' 'very nice and accommodating' approaches, the teaching methods at the School A, and the value for time, especially during class hours.

As discussed in the preceding paragraphs, students' skills development, their attitude towards learning and their relationship with other people have actually improved. However, it can be observed that this can only be true for students who actually started and finished the immersion program on the agreed duration or period. This is why as an area for improvement, the study reiterates on students' commitment to the program.

As regards the management of the program, the partner schools are commended for taking the initiative to conduct the immersion program which was actually the first in their Schools Division. However, certain areas must be addressed. This is not surprising because as the first initiative in the said Schools Division, it is not expected that it would turn out perfectly. Besides, all programs have their own strengths and development needs and nothing is perfect at any stage (Vega, Billot, \& Torrico, 2013; Ingersoll \& Strong, 2011). Maybe, in this program, it suffered from the so-called 'labor pain', for courageously approaching the demands and requirements of initiating a program like this one.

In the management of the program, this study highlights the findings that most responses have in common. From the data, it is found that from the total of 24 student-participants, 19 of them knew the real purpose or objectives of the students' immersion program which are to help the School B students in their academic life and to help them be immersed in a bigger world, to a new culture, a new environment, and a new way of learning. Just like the parent-participants, the student-participants also knew that this program is a collaboration of two participating schools. This knowledge of the objectives of the immersion program is a little surprising because 14 of the student-participants admitted that they were not oriented about the details of the program. They assert that even their parents were not personally oriented by the school's program implementers. They said that a letter containing the details of the program and a request for parental consent was just sent to their respective parents/guardians for their signature. This was confirmed by the responses of the parent-participants who added that they are not so sure if their children were properly oriented by the school before they were sent to the School A. The said claim was also verified by the School B teacher-in-charge of the program who said that she does not remember any activity or orientation to students where the details of the program were thoroughly discussed.

The rest of the student-participants claimed that they were only oriented by their respective advisers, while the others by the OIC/School Head in some instances. The responses of the student-participants and the parent-participants regarding the lack of proper orientation are not surprising since no other than the teacher-in-charge of the program at the partner school (School B) admitted that she was not also oriented about the details of the program. In fact, according to her, she was only told to be the chaperone of the students during 
the immersion and her role was limited to accompanying them and monitoring their attendance. Unlike the said teacher-in-charge, the one assigned at the School A, the leader school, was properly oriented of her roles and responsibilities in the program. She furthered that she had active participation in the crafting of the program itself, which includes the preparation or planning stage. From these data, this undertaking takes cognizance that proper orientation and information dissemination of any program, especially to its end users, are very crucial (Oo, Sutheerawatthana, \& Minato, 2010; Olubunmi \& Olushola, 2013) and all program implementers should always take this into consideration. Proper relaying of information particularly logistical matters and details are very significant in the success of any endeavor.

The respective school head-participants and teacher-participants of the two partner schools also mentioned about their experiences in the various stages of the program. The study believes that dealing with these experiences will greatly help in the assessment of the program in so far as its management is concerned. Assessing what went through before, during, and after the program will greatly help the study to see what really transpire $\mathrm{d}$, and in turn, will help it properly address the development needs of the program.

The data show that at the preparation or planning stage, the leader school "determined the needs of the partner school, its teachers and students, through series of meetings, phone calls and other forms of communication between the leader school and the partner school" to which the partner school agreed. It furthered that the program specifically designed for students as end-users were really determined because both schools would like to give benefits to the subject students in a direct means. To make sure that this program would run smoothly, teachers at the respective schools were also assigned as teachers-in-charge of the program. As previously mentioned, even the teacher-participant in the leader school participated actively in this crafting of the program. It could have been better should the teacher-in-charge in the partner school was also given the same extent of involvement.

Undeniable, there were also some concerns during this planning stage. On the part of the leader school, the safety of the students was on the top of the list because, despite the fact that a Memorandum of Agreement (MOA) was inked by the two participating schools, the leader school assumes full responsibility of the students whenever they are at the School A. The partner school agreed to this, adding that concerns on transportation, travel time and other security considerations are also major points to be considered. On the part of the teacher-participants, the fact that this program was an additional task was also mentioned. One of these participants, however, mentioned her lack of orientation at this stage which greatly affected the performance of her duties and responsibilities in the program.

At the execution stage, monitoring of the students' progress was done via qualitative means, that is, the data show, by simply asking the students and their student-mentors about their progress, experiences, and other concerns in the immersion program. As much as the schools would like to assess their progress quantitatively, the same is difficult because of two reasons: the 3-day and 2-day schedule where performance and quizzes at the School A are not recorded at the School B, and the fact that there had been three batches of students who participated in the program. These two reasons top the list of concerns of both schools as evidenced in their responses to the interviews. The last one, the concern on having three batches of participants, was also considered by this study as a major setback of the program. This is because of the fact that it is very difficult to assess the impact of the program on the participating students when only three of them successfully finished the program in its complete duration of four months.

At the evaluation stage, both schools agree that the least they can do in the evaluation of the program is to secure the responses of the participants to inquiries on their progress. The partner school made mention that it asked the students to write reflection papers about their experiences in the program.

Of all the things that all groups of participants would like to change in the immersion program, the schedule tops the list. As previously mentioned, for four months, the School B students go to School A for their classes from Monday to Wednesday, and they stay at School B from Thursday to Friday. This schedule, according to the 
student-participants, does not really help them in boosting their academic performance but only makes them confused in terms of attendance and recording of their assessments. 13 out of 24 student-participants prefer a schedule that is entirely a quarter, meaning, instead of following the 3-day School A and 2-day School B schedule, the students should be immersed for one quarter solely at School A. Following the concern on schedule is the necessity for proper students' orientation about the details of the program. The distance of the School B from the School A was also mentioned by 3 student-participants, indicating that a leader school near the School B should be chosen instead. One student-participant also mentioned about the concern on the recording of quizzes and performance at the School B. Another factor that was mentioned by both student-participant and parent-participant is the fact that in some instances, some lessons at the School A are advanced, or late in other situations, compared to the student-participants' lessons at the School B.

Asked whether or not they would recommend the same immersion program to other students, the resounding affirmative response was given but the condition that certain changes and improvements be considered immediately followed.

Overall, the findings show that the program's success heavily relies on parameters and factors other than numbers or the academic performance and class report cards of the student-participants. Statistically, if the results of the immersion program will only be measured through the resulting academic performance of these people, the program definitely failed. Most of the student-participants claimed that they got lower grades in most of their subjects compared to their performance before they participated in the immersion program. Although some School B teachers gave considerations in recording the performance of the student-participants, said considerations were insufficient to fill for the lacking points or grades of the subject students. Even after the program in December 2016, concerns as regards students' decline in academic performance, were still received by the partner school. This is in addition to other concerns in the management of the program, specifically on its preparation or planning stage which was very crucial. Nevertheless, there is still great success and optimism in the implementation of the program in so far as other aspects or developments are concerned.

The highly developed skills of the students specifically in critical thinking, their resulting attitude towards learning, the program's effect on their relationship with other people, their immersion to a new learning environment, the insights they gained, all contribute to the success of the program in general. Here comes the realization that, indeed, the immersion program went beyond the numbers and touched the very heart and awareness of the student-participants on the value of education and holistic development. This is in consonance with the study of Borghans, Golsteyn, Heckman, and Humphries (2016) which posits that while numerical data such as grades, assessments, and other statistics are important parameters in education, the strengths in the said field or in the classroom setting may not just be confined with such data but should go beyond them and touch other factors, parameters, and even attitudes and skills. What students need is to really be prepared for the future which grades alone could not possibly give (Claxton, 2013).

\section{Conclusion and recommendation}

From the results and discussion, the study hereby concludes that generally, the students' immersion program was able to serve its purpose and it was the success of both the implementers and the end-users of the program. Despite the setback on students' commitment in the program and on increasing the academic performance of the students who participated in it, it still showed positive outcomes in various aspects and areas of development among the students. More than what the numbers can provide, the insights gained by the students and their total or holistic development as a result of the program are major points that must be highlighted.

The study humbly recommends that the immersion of students from one school to another school be adopted by all other schools in the Division. This is the view of the positive outcomes that are manifested in those students who joined the immersion program between School A and School B. Most results reflect the success of the program that can also be adopted by other institutions. For the development needs, the study recommends the 
Sanchez, R., \& Sarmiento, P. J.

following changes and improvements in the students' immersion program:

$>$ It is recommended that in the next implementations of the program, the partner schools, together with the support and commitment of students and their parents, device certain mechanisms to ensure the commitment of all parties to start and finish the program on an agreed duration or period. Contract of agreement and other incentives may also be crafted and provided for students who can complete the immersion program. Similarly, students' various reasons for not completing the immersion program on the agreed period have to be seriously considered, discussed and addressed by the partner schools so that commitment to start and finish the program may be ensured in the next implementation of the program.;

$>$ The study recommends that in the next implementation, grades of students before and after the implementation of the immersion program are statistically compared. This would just mean that as a prerequisite to this comparison, students should be able to start and finish the program on the agreed period of time and that they should be staying in School A every day and the arrangement or schedule of 3-day-School A and 2-day-School B is replaced. Otherwise, such comparison would be very difficult, if not confusing;

$>\quad$ The program may be improved through a better orientation on the purpose or objectives of the program, better communications to parents, and closer monitoring and evaluation of its implementation; and

$>\quad$ It is recommended that the schedule of the immersion program be changed. Instead of the 3 days at the School A and 2 days at the School B schedule, students should stay at the immersion school for one whole quarter.

\subsection{Limitations of the study}

The study is limited by the following considerations. The immersion program's impact on the academic performance and attitude towards learning of the student-participants may not be fully determined in this study because most of the students who were originally selected to join the program had withdrawn from it. Thus, a study focusing on such insufficiency of this undertaking is advised. The would-be researchers of this suggested study may employ as participants the few students who had successfully finished the program. As to the collaborative management practices of the two involved schools, the opinions or perceptions of the people who participated in the study might not at all cover, stand, or speak for the overall assessment of the program.

\section{References}

Borghans, L., Golsteyn, B. H., Heckman, J. J., \& Humphries, J. E. (2016). What grades and achievement tests measure. Proceedings of the National Academy of Sciences of the USA, 113(47), 13354-13359. https://doi.org/10.1073/pnas.1601135113

Braskamp, L. A., Braskamp, D. C., \& Merrill, K. (2009). Assessing progress in global learning and development of students with education abroad experiences. Frontiers: The Interdisciplinary Journal of Study Abroad, 18, 101-118. https://doi.org/10.36366/frontiers.v18i1.256

Christiano, R. (2014). The effects of multicultural immersion programs on students' multicultural competency development. Counselor Education Capstones, 7. Retrieved from https://openriver.winona.edu/counseloreducationcapstones/7

Claxton, G. (2013). What's the point of school? Rediscovering the heart of education. Oxford, UK: One World Publications.

Creswell, J. W. (2007). Qualitative inquiry and research design choosing among five traditions. Thousand Oaks, CA: Sage Publications.

Creswell, J. W., \& Plano Clark, V. L. (2007). Designing and conducting mixed methods research. Thousand Oaks,

96 Consortia Academia Publishing (A partner of Network of Professional Researchers and Educators) 
CA: Sage Publications.

DeBar, L. L., Schneider, M., Drews, K. L., Ford, E. G., Stadler, D. D., Moe, E. L., White, M., et al. (2011). Student public commitment in a school-based diabetes prevention project: Impact on physical health and health behavior. BMC Public Health, 11. https://doi.org/10.1186/1471-2458-11-711

Denzin, N. K. (1978). Sociological methods. New York, NY: McGraw-Hill.

Department of Education. (2016). DepEd Order No. 44, s. 2016, Guidelines on the School-to-School Partnerships for Fiscal Year 2016. Retrieved from https://www.deped.gov.ph/2016/06/23/do-44-s-2016-guidelines-on-the-school-to-school-partnerships-fo r-fiscal-year-2016/

Doyle, D. (2009). Holistic assessment and the study abroad experience. Frontiers: The Interdisciplinary Journal of Study Abroad, 18, 143-155. https://doi.org/10.36366/frontiers.v18i1.258

Greenholtz, J. (2000). Assessing cross-cultural competence in transnational education: The Intercultural Development Inventory. Higher Education in Europe, 25(3), 411-416. https://doi.org/10.1080/713669273

Ingersoll, R. M., \& Strong, M. (2011). The impact of induction and mentoring programs for beginning teachers: a critical review of the research. Review of Educational Research, 81(2), 201-233. https://doi.org/10.3102/0034654311403323

Kolb, D. (1984). Experiential learning as the source of learning and development. Englewood Cliffs, NJ: Prentice Hall.

Larson, L. C., \& Miller, T. N. (2011). 21st century skills: Prepare students for the future. Kappa Delta Pi Record, 47(3), 121-123. https://doi.org/10.1080/00228958.2011.10516575

Lincoln, Y. S., \& Guba, E. G. (1985). Naturalistic inquiry. Newbury Park, CA: Sage Publications. https://doi.org/10.1016/0147-1767(85)90062-8

Ogden, A. (2006). Ethnographic inquiry: Reframing the learning core of education abroad. Frontiers: The Interdisciplinary Journal of Study Abroad, 13, 87-112. https://doi.org/10.36366/frontiers.v13i1.175

Olubunmi, B., \& Olushola, I. (2013). Effects of information dissemination using video of indigenous language on 11-12 years children's dental health. Ethiopian Journal of Health Sciences, 23(3), 201-208. https://doi.org/10.4314/ejhs.v23i3.2

Oo, H. H., Sutheerawatthana, P., \& Minato, T. (2010). Comparison of information dissemination methods in Inle lake: A lesson for reconsidering framework for environmental education strategies. Applied Environmental Education \& Communication, 9(1), 58-74. https://doi.org/10.1080/15330150903566547

Paus, E., \& Robinson, M. (2008). Increasing study abroad participation: The faculty makes the difference. Frontiers: The Interdisciplinary Journal of Study Abroad, 17, 33-49. https://doi.org/10.36366/frontiers.v17i1.243

Steinberg, M. (2002). Involve me and I will understand: Academic quality in experiential programs abroad. Frontiers: The Interdisciplinary Journal of Study Abroad, 7, 207-229. https://doi.org/10.36366/frontiers.v8i1.100

Vega, C. A., Billot, C., \& Torrico, F. (2013). Achievements and challenges upon the implementation of a program for national control of Congenital Chagas in Bolivia: Results 2004-2009. PLOS Neglected Tropical Diseases, 7(7). https://doi.org/10.1371/journal.pntd.0002304 
Sanchez, R., \& Sarmiento, P. J.

98 Consortia Academia Publishing (A partner of Network of Professional Researchers and Educators) 